УДК 551.263.2.03 (571.65)

\title{
СЕРЕБРО-АРСЕНИДНАЯ ФОРМАЦИЯ ОМОЛОНСКОГО СРЕДИННОГО МАССИВА (новЫе даННЫе)
}

\author{
H. E. Савва \\ ФГБУН Северо-Восточный комплексный научно-исследовательский институт \\ им. Н. А. Шило ДВО РАН, г. Магадан \\ E-mail: savva@neisri.ru
}

\begin{abstract}
Изучены самородки серебра из шлиховых ореолов рудопроявления Седое. В срастании с самородным серебром установлены: кюстелит, ютенбогаардтит, биллингслеит - $\mathrm{Ag}_{7}(\mathrm{Sb}, \mathrm{As}) \mathrm{S}_{6}$, ксантоконит $-\mathrm{Ag}_{3} \mathrm{AsS}_{3}$, акантит и мышьяковистый акантит (As до 2.8 мас.\%), сфалерит, электрум, кобальтин никелистый (Ni до 4 мас.\%), трехманнит(?) - $\mathrm{AgAsS}_{2}$ никелистый, что опровергает высказанное ранее предположение об экзогенном происхождении самородков и подтверждает серебро-арсенидную рудноформационную принадлежность Седого. Показано, что шлиховые ореолы самородного серебра, расположенные вдоль Конгинского глубинного разлома, служат индикаторами проявления серебро-арсенидной формации на площади Омолонского срединного массива.
\end{abstract}

Ключевые слова: самородное серебро, серебро-арсенидная формация, Омолонский срединный массив.

DOI: 10.34078/1814-0998-2019-4-9-17

\section{ВВЕДЕНИЕ}

Среди сереброрудных формаций сереброарсенидная занимает особое положение. Многими исследователями показана ее приуроченность к краевым и срединным активизированным жестким массивам (Смирнов, 1982; Коваленкер и др., 1994; Антонов, 2009; и др.). Вулканические образования, излившиеся на поверхность по разломам древнего заложения в областях жестких консолидированных массивов, продуцируют месторождения серебра с рудами, контрастно отличающимися по химическому и минеральному составу от месторождений серебра вулканогенных поясов. Они более всего сходны с рудами так называемой пятиэлементной формации $(\mathrm{Ag}, \mathrm{U}, \mathrm{Co}$, $\mathrm{Bi}, \mathrm{As})$, развитыми на древних щитах и платформax, но не всегда содержат полный комплекс указанных элементов. Примером подобных месторождений могут служить Средне-Чешский район, Рудные Горы, Срединный Тянь-Шань и др. (Антонов, 2009). Согласно А. А. Сидорову и др. (2011), серебро-арсенидная формация может входить в рудноформационный ряд базовой - пятиэлементной.

Месторождения серебро-арсенидной формации известны на площади Омолонского сре-

\footnotetext{
(C) Савва Н. Е., 2019
}

динного массива, активизированного в девонраннекарбоновое время, а также в раннем мелу по зоне Конгинского глубинного разлома. Разлом имеет северо-северо-западное простирание, протягиваясь от Охотского побережья в глубь Евразийского материка. Для Северо-Восточной металлогенической провинции его направление совпадает с одним из главных рудоконтролирующих направлений. К настоящему времени также изучены проявления серебро-арсенидной минерализации в басс. р. Правая Визуальная, верховьях p. Русская-Омолонская, руч. Бодрый и Ольдяни. Характерно, что все они приурочены к выступам архейского фундамента и продуцируют россыпи самородного серебра, промышленная ценность которых до сих пор однозначно не установлена. Нами получены новые данные, свидетельствующие о гипогенной природе самородков серебpa, которые ранее мы считали гипергенными, что дает больше оснований говорить о сереброарсенидной формации на Омолонском массиве.

\section{МЕТОДЫ ИССЛЕДОВАНИЙ}

Проанализировано 14 зерен самородного серебра в монтированном аншлифе. Оптическое изучение выполнено на микроскопе Axioplan Imagin с цифровой фотонасадкой Orbitron. Составы минеральных фаз определяли рентге- 
носпектральным электронно-зондовым микроанализатором Camebax с приставкой INCA Instrument Oxfofd в СВКНИИ ДВО РАН, аналитик Е. М. Горячева. Режим проведения анализов: напряжение - 20 кВ, аналитические линии и эталоны: As $L \alpha$ - эталон - FeAsS (43.49 - As; 34.97 Fe; $21.54-\mathrm{S})$; $\mathrm{CoK} \alpha, \mathrm{NiK \alpha}$ - эталон - NiCoFe $(29-\mathrm{Ni} ; 17-\mathrm{Co} ; \mathrm{Fe}-54) ; \mathrm{CuK \alpha}$ - эталон - $\mathrm{CuFeS}$ $(34.5$ - $\mathrm{Cu} ; 30.5-\mathrm{Fe} ; 34.5-\mathrm{S})$; Fe $K \alpha$ - эталон $\mathrm{FeS}_{2}(46.55$ - Fe); $\mathrm{Pb} M \alpha$ - эталон - $\mathrm{PbS}(86.6$ $\mathrm{Pb}) ; \mathrm{SbL} \alpha-$ эталон - $\mathrm{Sb}_{2} \mathrm{~S}_{3}(71.38-\mathrm{Sb}) ; \mathrm{SeK} \alpha-$ эталон - PbSe (27.6 - Se); ZnK $\alpha$ - эталон - ZnS $(67.1-\mathrm{Zn}) ; \operatorname{Ag} L \alpha-$ эталоны - сплавы различного состава.

\section{КРАТКОЕ ОПИСАНИЕ ОБЪЕКТА И РЕЗУЛЬТАТЫ ИССЛЕДОВАНИЙ}

Омолонский срединный массив (иначе - Омолонский кратонный террейн, микроконтинент) расположен на территории Магаданской области. В его строении четко различаются древний метаморфический фундамент и осадочный чехол, а также позднемеловой молассовый комплекс и вулкано-плутонические образования раннемелового активизационного этапа.

С конца 1970-1980-х гг. в геологической литературе появились упоминания о находках самородного серебра в шлиховых ореолах на территории Омолонского срединного массива (Показаньев и др., 1980). В начале 1980-х гг. в южной части Кедонского поднятия были проведены литогеохимические поиски по потокам рассеяния и получены новые данные о распространении, минералогических особенностях и геологических условиях проявления шлихового самородного серебра (Павлов и др., 1986).

Рудопроявление Седое обнаружено автором в ходе поисковых работ и подробно описано в рукописных работах и публикациях (Савва, Ведерников, 1989; Савва, 1999, 2018; Геология..., 2017). Указанное рудопроявление приурочено к Ауланджинскому выступу фундамента Омолонского массива и расположено на правобережье устьевой части руч. Седой, правого притока p. Русская-Коркодонская. Площадь сложена толщей известняков и доломитов с прослоями алевролитов ордовика, несогласно перекрытых риолитами и игнимбритами кедонской серии. Известняки прорваны небольшими телами и дайками биотитовых гранодиоритов и монцодиоритов булунского комплекса раннего карбона, по-видимому, являющихся апофизами Гэлбэтинского массива, обнажающегося восточнее, на правобережье руч. Седой. Вдоль контактов тел развиты поля скарнов и скарноидов мощностью 50-100 м, скарновополиметаллические залежи с теллуридами $\mathrm{Pb}, \mathrm{Bi}$, $\mathrm{Au}, \mathrm{Ag}$, а также сульфидно-кварц-флюоритовые прожилки и линзы. На северо-западном фланге рудопроявления обнажается экструзия риолитов, в контактовой зоне которой содержатся обломки известняков и кварца. Рудные тела - полого залегающие послойные жилы и крутопадающие полиметаллические залежи в ордовикских известняках.

Формирование рудной минерализации полихронное - от ордовика до раннего мела и проходило в три этапа: метаморфогенный, связанный с региональным и контактовым метаморфизмом известковистых осадочных толщ - додевонский; девонский - вулкано-плутонический, как результат магматической активизации; вулканогенный - раннемеловой (этап поздней активизации), связанный с формированием Конгинской ветви Охотско-Чукотского вулканогенного пояса (ОЧВП). Длительная история формирования руд подтверждается также модельным возрастом свинца из галенита карбонатно-полисульфидных жил, локализованных в риолитах. Он по данным изотопного анализа равен 676 млн лет и соответствует ордовику (Шпикерман и др., 1993). Подобным образом руды Кер-д’Ален, продолжительное время считавшиеся ларамийскими, после исследования изотопного состава свинца, который оказался докембрийским, хотели отнести к более древнему возрасту. В связи с этим появились сомнения - либо главная стадия минерализации относится к докембрию, либо она образовалась позже и произошел вынос (регенерация) галенита из источника, имеющего докембрийский возраст (Антонов, 2009).

Текстурной особенностью сереброносных манганокальцитовых жил являются: вкрапленная, массивная (сливной галенит), а также колломорфная с существенно леллингитовой и кобальт-леллингитовой ассоциацией, в интерстициях которой отлагались сульфосоли серебра (рис. 1,А).

В области сноса сереброносных манганокальцитовых жил в донных отложениях руч. Седой были встречены многочисленные зерна (2-15 мм) самородного серебра средней и слабой окатанности. Морфология зерен разнообразная - комковидная, дендритовидная, сростки и слабоокатанные кристаллические агрегаты (рис. 1,Б, $a-8$ ).

Минералогические исследования самородков серебра из шлиховых ореолов показали его гипогенную, а не гипергенную природу, как считалось ранее. В зернах самородного серебра при их вскрытии (в аншлифах) оказались многочисленные включения не только метасоматического серицита и каолинита, но и ряда рудных минералов гипогенного происхождения, среди них: сфалерит ( $\mathrm{Fe}$ - не более 0.35 мас.\%), биллингслеит - $\mathrm{Ag}_{7}(\mathrm{Sb}, \mathrm{As}) \mathrm{S}_{6}$, ксантоконит - $\mathrm{Ag}_{3} \mathrm{AsS}_{3}$, акантит и мышьяковистый акантит (As до 2.8 мас.\%), кобальтин никелистый (Ni до 4 мас.\%), трехманнит? - $\operatorname{AgAsS}_{2}$ никелистый (табл. 1; рис. 1, Б, $2-\varkappa)$. 
A

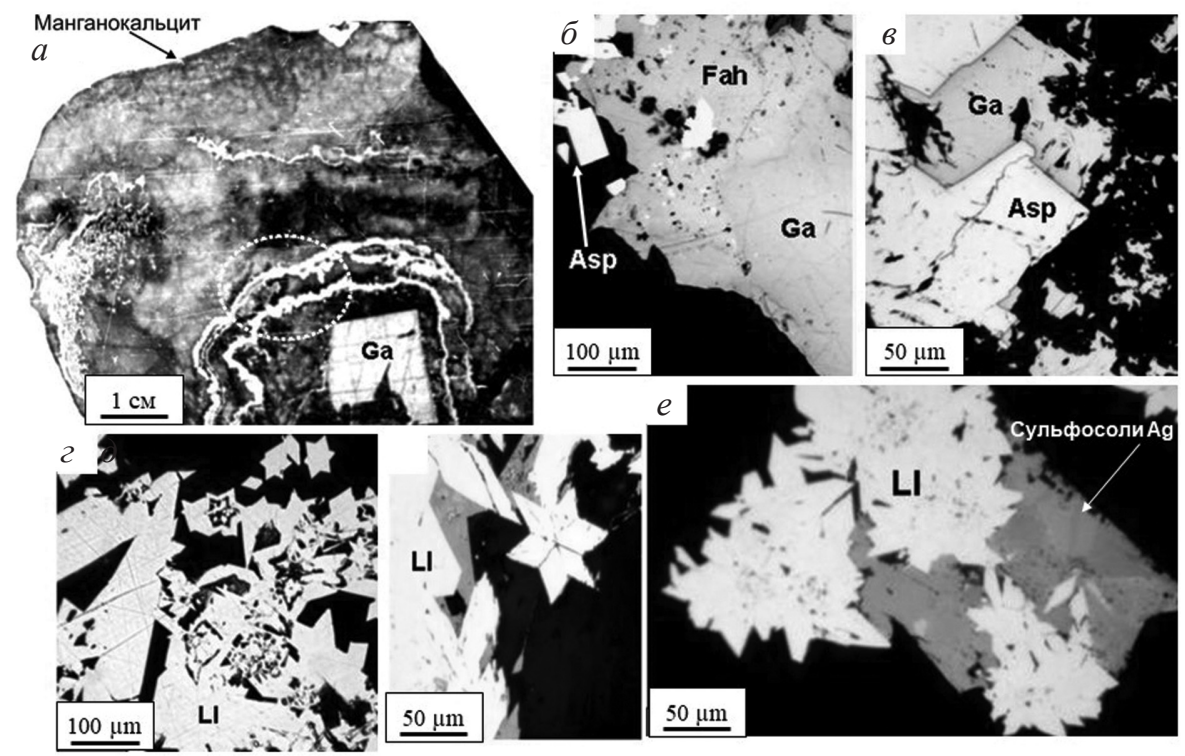

Б

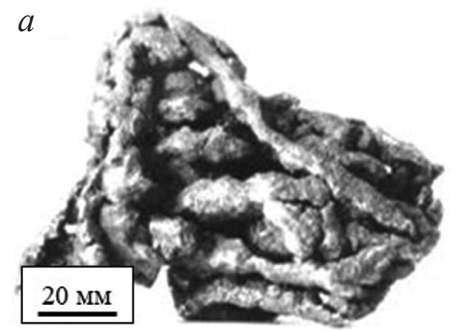

$\sigma$
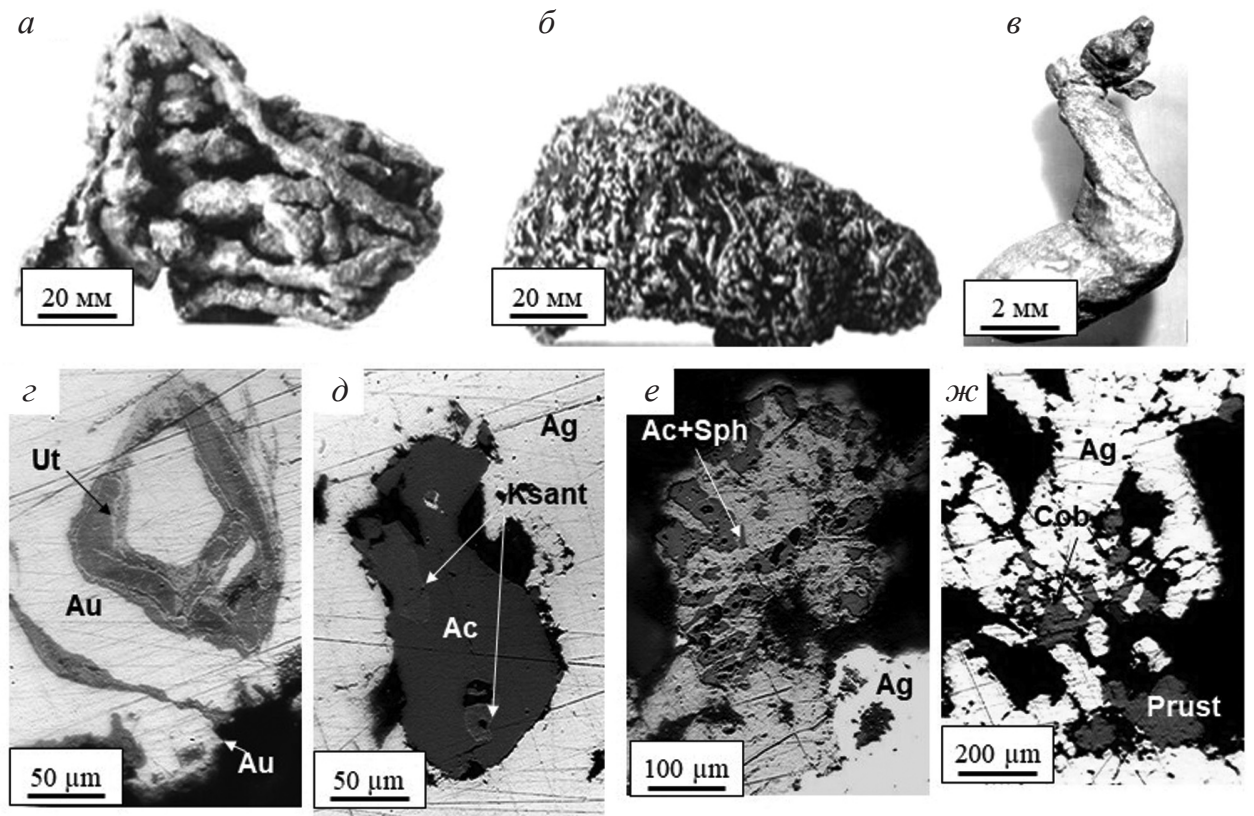

Puc. 1. Минеральные ассоциации руд серебро-арсенидной формации: $\mathbf{A}, a-$ фрагмент манганосидеритовой жилы с вкраплением обломочного галенита и колломорфными образованиями кобальтистого леллингита, срастающегося с сульфосолями серебра; $\sigma, \varepsilon$ - наложение позднего арсенопирита на галенит и фрейбергит (рудное проявление в басс. руч. Правый Визуальный); $6-\partial$ - рудопроявление Седое: 8 - типичное выделение кобальтистого леллингита (Со до 1.7 мас.\%) в манганосидерите; $2-e-$ ассоциация сульфосолей серебра (прустита, пираргирита, биллингслеита) с кобальтистым леллингитом; Б, $a-8$ - самородки серебра из россыпей Омолонского массива; 2-ж- минеральные срастания в самородках: 2 - срастание кюстелита с гипергенным ютенбогаардтитом; $\partial$ - включение в самородном серебре акантита и ксантоконита; $e$ - срастание самородного серебра с минеральным агрегатом акантита и сфалерита; ж- включения никелистого кобальтина и прустита в самородном серебре

Fig. 1. Mineral associations of silver-arsenide formation ores: A, $a$ - fragment of manganosiderite vein with impregnated fragments of galena and colloforms of cobaltous loellingite intergrowing with silver sulfosalts; $\sigma, \beta-$ imposition of later arsenopyrite on galena and freibergite ( occurrence in the basin of the Pravy Visualny Creek; $b-\partial-$ Sedoy occurrence: 6 - typical separation of cobalt loellingite (Co up to $1.7 \mathrm{wt} \%$ ) in manganosiderite; $2, \partial$ - association of silver sulfosalts (proustite, pyrargyrite, billingsleyite) with cobaltous loellingity ; $\mathbf{6}, a-b-$ silver nuggets from the Omolon massif placers; $2-\mathscr{c}$ - mineral intergrowths in nuggets: 2 - kustelite intergrowth with hypergenic uytenbogaardtite; $\partial$ - inclusion of acanthite and xanthoconite in native silver; $e$-native silver intergrowth with the mineral aggregate of acanthite and sphalerite; $\nRightarrow$-inclusions of nickelous cobaltite and proustite in native silver 
Таблица 1. Состав включений рудных минералов в самородках серебра по данным рентгеноспектрального анализа

Table 1. Composition of the ore mineral inclusions in silver nuggets according to X-ray spectrometry

\begin{tabular}{|c|c|c|c|c|c|c|c|c|c|c|c|c|}
\hline \multicolumn{7}{|c|}{ Концентрация элементов, мас.\% } & \multicolumn{6}{|c|}{ Формульные коэффициенты } \\
\hline \multicolumn{13}{|c|}{ Ютенбогаардтит $\mathrm{AuAg}_{3} \mathrm{~S}_{2}$} \\
\hline $\mathrm{S}$ & $\mathrm{Ag}$ & $\mathrm{Au}$ & $\mathrm{Fe}$ & As & $\mathrm{Sb}$ & $\sum$ & $\mathrm{S}$ & $\mathrm{Ag}$ & $\mathrm{Au}$ & $\mathrm{Fe}$ & As & $\mathrm{Sb}$ \\
\hline 10.06 & 46.28 & 35.52 & & & & 91.86 & 2.04 & 2.79 & 1.48 & & & \\
\hline \multicolumn{13}{|c|}{ Петровскаит AuAgS } \\
\hline 10.56 & 27.44 & 53.51 & 2.96 & & & 94.47 & 1.09 & 0.84 & 1.11 & 0.17 & & \\
\hline 11.40 & 29.66 & 55.99 & 1.84 & & & 98.89 & 1.13 & 0.87 & 1.16 & 0.10 & & \\
\hline \multicolumn{13}{|c|}{ Биллингслеит $\mathrm{Ag}_{7}(\mathrm{Sb}, \mathrm{As}) \mathrm{S}_{6}$} \\
\hline $\mathrm{S}$ & $\mathrm{Ag}$ & As & $\mathrm{Sb}$ & Co & $\mathrm{Ni}$ & $\sum$ & $\mathrm{S}$ & $\mathrm{Ag}$ & As & $\mathrm{Sb}$ & $\mathrm{Co}$ & $\mathrm{Ni}$ \\
\hline 13.61 & 80.34 & 6.26 & 3.53 & & & 103.74 & 4.54 & 7.96 & 0.89 & 0.31 & & \\
\hline 13.35 & 79.80 & 6.70 & 3.32 & & & 103.17 & 4.49 & 7.97 & 0.96 & 0.29 & & \\
\hline 14.77 & 82.36 & 5.15 & 1.80 & & & 104.08 & 4.88 & 8.08 & 0.73 & 0.16 & & \\
\hline 11.98 & 75.67 & 4.50 & & 2.32 & 1.14 & 95.61 & 4.38 & 8.22 & 0.70 & & 0.22 & 0.01 \\
\hline \multicolumn{13}{|c|}{ Кобальтин (Co, Ni, Fe) AsS } \\
\hline 15.05 & 12.53 & 39.57 & 0.61 & 19.66 & 9.03 & 96.45 & 0.87 & 0.22 & 0.98 & 0.02 & 0.62 & 0.29 \\
\hline 17.88 & & 45.52 & 1.76 & 23.10 & 9.46 & 97.72 & 0.96 & & 1.04 & 0.05 & 0.67 & 0.28 \\
\hline \multicolumn{13}{|c|}{ Акантит $\mathrm{Ag}_{2} \mathrm{~S}$} \\
\hline $\mathrm{S}$ & $\mathrm{Ag}$ & As & & & & $\sum$ & $\mathrm{S}$ & $\mathrm{Ag}$ & As & & & \\
\hline 11.94 & 84.57 & & & & & 96.51 & 0.97 & 2.03 & & & & \\
\hline 14.13 & 86.53 & & & & & 100.66 & 1.06 & 1.94 & & & & \\
\hline 12.58 & 84.12 & 0.97 & & & & 97.67 & 0.99 & 1.97 & 0.03 & & & \\
\hline 13.56 & 84.05 & 2.77 & & & & 100.38 & 1.02 & 1.89 & 0.09 & & & \\
\hline \multicolumn{13}{|c|}{ Ксантоконит $\mathrm{Ag}_{3} \mathrm{AsS}_{3}$} \\
\hline $\mathrm{S}$ & As & $\mathrm{Ag}$ & $\mathrm{Sb}$ & & & $\sum$ & $\mathrm{S}$ & As & $\mathrm{Ag}$ & $\mathrm{Sb}$ & & \\
\hline 18.55 & 13.03 & 68.97 & 1.58 & & & 102.13 & 2.88 & 0.03 & 3.18 & 0.06 & & \\
\hline \multicolumn{13}{|c|}{ Минеральная смесь (трехманнит $\mathrm{AgAsS}_{2}$ ? + аллоклазит (Co,Ni) AsS?) } \\
\hline $\mathrm{S}$ & $\mathrm{Ag}$ & As & $\mathrm{Fe}$ & Co & $\mathrm{Ni}$ & $\sum$ & $\mathrm{S}$ & $\mathrm{Ag}$ & As & $\mathrm{Fe}$ & $\mathrm{Co}$ & $\mathrm{Ni}$ \\
\hline 14.12 & 35.90 & 24.12 & 1.00 & 12.28 & 6.29 & 93.71 & 1.23 & 0.93 & 0.90 & 0.05 & 0.58 & 0.30 \\
\hline 18.61 & 13.10 & 69.28 & 1.99 & & & 102.98 & 2.87 & 0.09 & 3.18 & 0.08 & & \\
\hline \multicolumn{13}{|c|}{ Сфалерит } \\
\hline $\mathrm{S}$ & $\mathrm{Fe}$ & $\mathrm{Zn}$ & $\mathrm{Ag}$ & & & $\sum$ & $\mathrm{S}$ & $\mathrm{Fe}$ & $\mathrm{Zn}$ & $\mathrm{Ag}$ & & \\
\hline 32.48 & 0.48 & 62.44 & 2.73 & & & 98.13 & 1.01 & 0.01 & 0.95 & 0.03 & & \\
\hline \multicolumn{13}{|c|}{ Сфалерит + самородное серебро } \\
\hline 25.07 & 0.36 & 43.80 & 25.17 & & & 94.40 & & & & & & \\
\hline
\end{tabular}

Минеральные включения в самородном серебре ксеноморфные и имеют размеры от 0.07 до 1.2 мм. Отмечаются сложные срастания акантита, цементирующего обломки сфалерита (рис. $\mathbf{1 , \mathbf { 6 }}, e$ ) - результат ступенчатости (стадийности) процесса рудообразования. Состав большинства рудных включений нестехиометричен, что характерно для резко градиентных эпитермальных условий формирования руд.
Среди самородков серебра были выявлены также зерна кюстелита неоднородного строения с гипергенными каймами петровскаита и ютенбогаардтита (рис. 1,Б,2; см. табл. 1).

Гистограмма пробности кюстелита двумодальная (рис. 2) (с двумя пиками в областях 200 и 350\%), что также отражает стадийное минералообразование; среднее значение пробности $-335 \%$. 


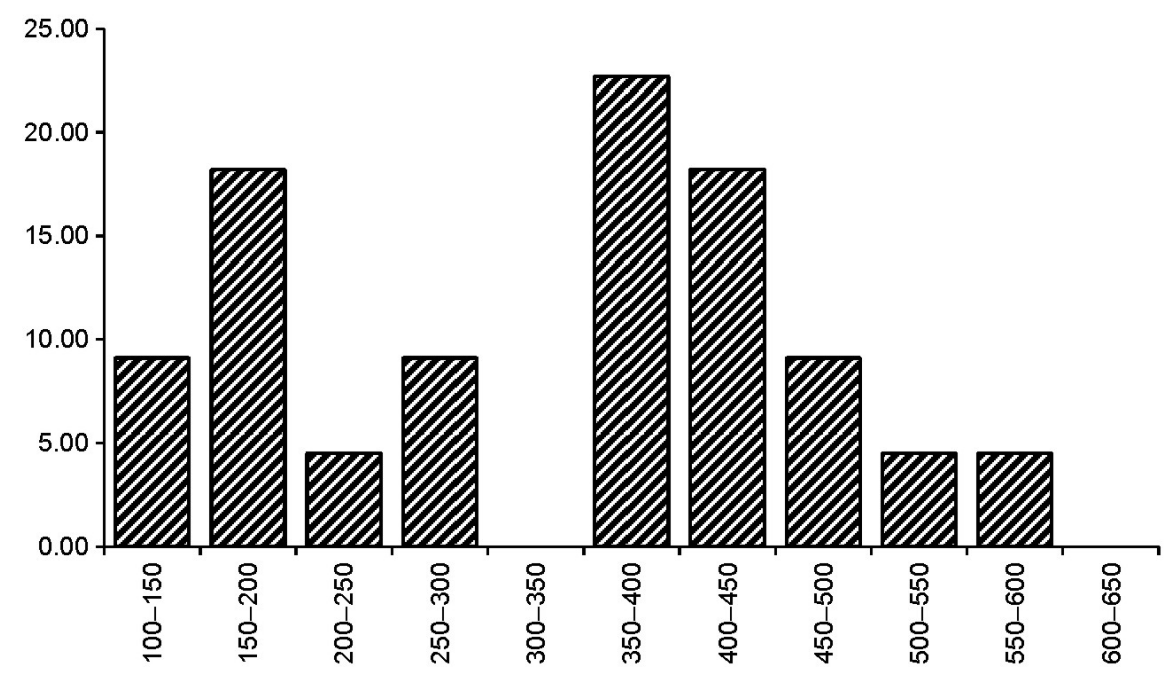

Puc. 2. Гистограмма пробности самородного золота из серебро-арсенидного проявления Седое: по оси абсцисс - интервалы пробности, \%о; по оси ординат - частота встречаемости, \%

Fig. 2. Histogram of fineness of native gold from the Sedoy silver-arsenide occurrence : X-line shows fineness intervals $(\%)$; Y-line, degree of incidence $(\%)$

\section{ОБСУЖДЕНИЕ РЕЗУЛЬТАТОВ}

В целом описанная минерализация существенно отличается от сереброрудных проявлений Охотско-Чукотского вулканогенного пояса как по текстурам руд, так и по составу и последовательности формирования минеральных парагенезисов. В минералогическом плане наиболее существенным отличием является отложение минералов мышьяка после минералов свинца и цинка, а также парагенезис серебряных минералов с кобальтистым леллингитом.

Примесь никеля и кобальта в леллингите на уровне целых процентов сближает описанную минерализацию с пятиэлементной. Этому способствует и то обстоятельство, что в толще ордовикских известняков имеются горизонты, насыщенные гематитом, который постоянно сопровождает месторождения указанной формации.

Данные, полученные в ходе исследования минеральных рудных включений в самородках серебра, подтвердили его гипогенное происхождение, а высокая химическая чистота самородного серебра, выявленная не только нами, но и A. Changkakoti и R. D. Morton (1986) для месторождений Канадского щита, позволяет с еще большей убежденностью относить рудопроявление к серебро-арсенидной формации.

Формирование руд серебро-арсенидной формации и связанных с ней россыпей серебра в зоне долгоживущего Конгинского разлома полихронно и полистадийно, что обусловило многократное перераспределение рудного вещества. При этом большое влияние на хи- мическую специализацию руд оказал древний высокожелезистый субстрат, на котором формировались более поздние вулканические образования. Это железистые кварциты с повышенными концентрациями $\mathrm{Fe}, \mathrm{Co}, \mathrm{Ni}$, $\mathrm{As}$, a также палеозойские осадочные породы с рассеянными в них $\mathrm{Pb}$ и $\mathrm{Zn}(\mathrm{Pb}$ и $\mathrm{Zn}$ до сотен граммов на 1 т).

Нанесенные на геологическую схему (рис. 3) ареалы развития шлихового самородного серебра трассируют Омолонский массив вдоль Конгинского глубинного разлома. Также отмечается постоянная приуроченность этих ареалов к выступам древнего фундамента на площади массива - Рассошинскому, Абкитскому, Ольдянскому, Кедонскому, Ауланджинскому.

Проведенное нами сравнение серебро-арсенидной минерализации Омолонского срединного массива с другими провинциями мира (табл. 2) выявило много общих черт в геологическом строении и минералого-геохимических особенностях, среди них:

активизация крупных древних блоков земной коры;

постоянное присутствие в рудах самородного серебра;

геохимическая специализация $\mathrm{Fe}, \mathrm{Ag}, \mathrm{As}, \mathrm{Ni}$, $\mathrm{Co}, \mathrm{Bi}, \mathrm{Pb}$, а в ряде случаев и $\mathrm{U}$;

регенерированный древний $\mathrm{Pb}$ в более молодых рудах (Седое, Правое Визуальное, Серебряный пояс Кер-д’Ален в США, штат Айдахо);

пространственная приуроченность к выходам древних пород. 


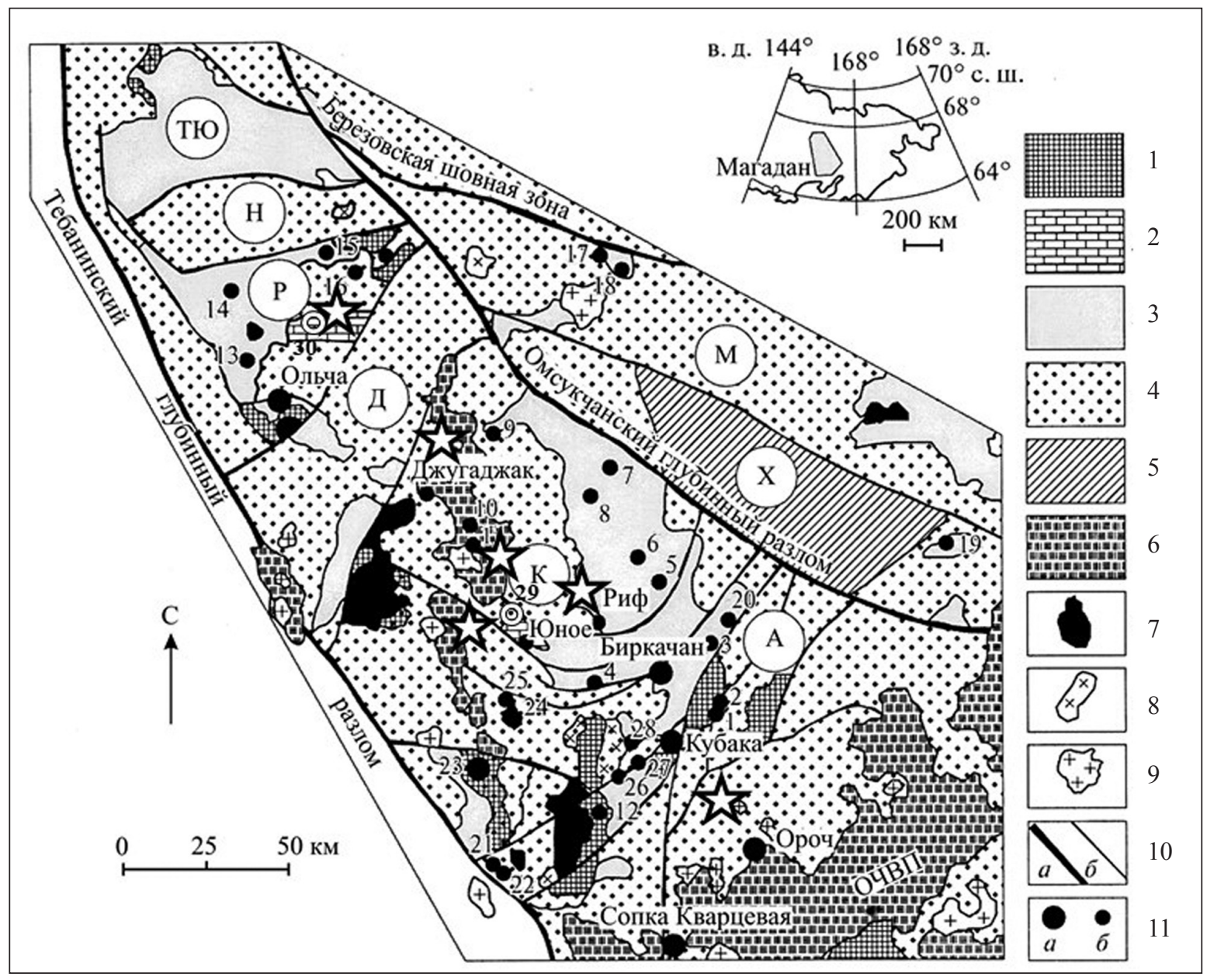

Pис. 3. Ареалы шлихового самородного серебра (обозначены звездами) на территории Омолонского кратонного террейна (Волков и др., 2011) с добавлениями: 1 - выходы архейского кристаллического фундамента; 2 - выходы нижнего этажа чехла массива; 3 - выходы среднего этажа чехла массива (рудовмещающая кедонская серия КВП); 4 - верхний этаж чехла массива; 5 - Хуличанская раздвиговая впадина (Х); 6 - меловые вулканиты (Охотско-Чукотский вулканогенный пояс); 7 - гранитоидные массивы абкитского комплекса; 8 - палеозойские гранитоидные массивы; 9 - меловые гранитоиды; 10 - ранг разломов: $a$ - краевые швы, $\sigma$ - межблоковые ограничения; 11 - палеозойские золото-серебряные месторождения $(a)$ и проявления (б). Рудопроявления: 1 - Таборное, 2 - Орлиное, 3 - Надежда, 4 - Хунгандя, 5 - Туманное, 6 - Маловодное, 7 - Шеелитовое, 8 - Рыжик, 9 - Обыкновенное, 10 - Бодрое, 11 - Упрямое, 12 - Елочка, 13 - Артур, 14 - Подгорное, 15 - Юное, 16 - Олень, 17 - Извилистое, 18 - Медь-Гора, 19 - Круторогое, 20 - Бургали, 21 - Джелтинское-1, 22 - Джелтинское-2, 23 - Верхне-Омолонское, 24 - Хрустальное, 25 Вечернее, 26 - Инняга, 27 - Пробное, 28 - Магнитное, 29 - Седое; 30 - Правое Визуальное. Блоки: ТЮ Тарын-Юряхский, Р - Рассошинский, К - Кедонский, А - Ауланджинский. Зоны: Н - Ненкальская, Д - Доломнанская, М - Моланджинская

Fig. 3. The areas of native placer silver (designated by stars) around the Omolon craton terrain (Volkov et al., 2011) with additions: 1 - outcrops of the Archaean crystalline basement; 2 - outcrops of the lower floor of the massif cover; 3 - outcrops of the middle floor of the massif cover (ore-bearing Kedon series of KVB ); 4 - top floor of the massif cover; 5 - Khulichan fault depression (X); 6 - Cretaceous volcanites (Okhotsk-Chukotka volcanic belt); 7 - granitoid massifs of the Abkit complex; 8 - Paleozoic granitoid massifs; 9 - Cretaceous granitoids; 10 - rank of faults: $a$ - edge sutures, $\sigma$-interblock restrictions; 11 - Paleozoic gold-silver deposits $(a)$ and occurrences (б). Occurrences: 1 - Tabornoye, 2 - Orlinoye, 3 - Nadezhda, 4 - Khungandya, 5 - Tumannoye, 6 - Malovodnoyoe, 7 - Sheyelitovoye, 8 - Ryzhik, 9 - Obyknovennoye, 10 - Bodroye, 11 - Upryamoye, 12 - Yolochka, 13 - Arthur, 14 - Podgornoye, 15 - Yunoye, 16 - Olen', 17 - Izvilistoye, 18 - Med'-Gora, 19 - Krutorogoye, 20 - Burgali, 21 - Dzheltinskoye-1, 22 - Dzheltinskoye-2, 23 - Verkhneomolonskoye, 24 - Khrustal'noye, 25 - Vecherneye, 26 - Innyaga, 27 - Probnoye, 28 - Magnitnoye, 29 - Sedoy, 30 - Pravy Vizualny. Blocks: TЮ - Taryn-Yuryakh, P - Rassoshinsky, K - Kedon, A - Aulandza. Areas: H - Nenkal', D - Dolomnan, M Molandzha 
Таблища 2. Сравнение месторождений серебро-арсенидной формации Омолонского срединного массива с месторождениями других регионов

Table 2. Comparison of silver-arsenide formation deposits of the Omolon median massif with deposits in other regions

\begin{tabular}{|c|c|c|c|c|}
\hline \multirow[b]{2}{*}{ Элементы сравнения } & \multicolumn{4}{|c|}{ Рудные районы } \\
\hline & $\begin{array}{c}\text { Омолонский массив } \\
\text { (Россия, Магаданская } \\
\text { область) }\end{array}$ & $\begin{array}{c}\text { Таласский Алатау* } \\
\text { (Киргизия) }\end{array}$ & $\begin{array}{c}\text { Рудные Горы** } \\
\text { (Чехия, Германия) }\end{array}$ & $\begin{array}{c}\text { Серебряный пояс } \\
\text { Кер-д’Ален** } \\
\text { (США, штат } \\
\text { Айдахо) }\end{array}$ \\
\hline Вмещающие породы & $\begin{array}{l}\text { Известковистые поро- } \\
\text { ды протерозоя (ви- } \\
\text { зейская и сезамская } \\
\text { толщи); ордовикские } \\
\text { известняки }\end{array}$ & $\begin{array}{l}\text { Вехнерифейские } \\
\text { сланцы, переслаива- } \\
\text { ющиеся с полимик- } \\
\text { товыми песчаника- } \\
\text { ми и известняками }\end{array}$ & $\begin{array}{l}\text { Протерозойские, } \\
\text { реже нижнепалео- } \\
\text { зойские кристалли- } \\
\text { ческие сланцы и } \\
\text { гнейсы }\end{array}$ & $\begin{array}{l}\text { Докембрийские } \\
\text { аргиллиты, квар- } \\
\text { циты с прослоями } \\
\text { карбонатных по- } \\
\text { род }\end{array}$ \\
\hline $\begin{array}{l}\text { Интрузивные по- } \\
\text { роды }\end{array}$ & $\begin{array}{l}\text { Лейкократовые гра- } \\
\text { ниты, гранодиори- } \\
\text { ты, сиениты; рио- } \\
\text { литы ранне-поздне- } \\
\text { мелового возраста }\end{array}$ & $\begin{array}{l}\text { Плагиограниты, } \\
\text { лейкократовые } \\
\text { граниты, сиениты, } \\
\text { сиенит-порфиры, } \\
\text { дайки диабазовых } \\
\text { порфиритов постме- } \\
\text { лового возраста }\end{array}$ & $\begin{array}{l}\text { Позднекарбоновый } \\
\text { Эйбенштонский гра- } \\
\text { нитный массив, дай- } \\
\text { ки гранит-порфиров; } \\
\text { базальты и диабазы } \\
\text { постмелового воз- } \\
\text { раста }\end{array}$ & $\begin{array}{l}\text { Штоки и дайки } \\
\text { монцонитоидов, } \\
\text { диабазов, андези- } \\
\text { тов позднемелово- } \\
\text { го возраста }\end{array}$ \\
\hline $\begin{array}{l}\text { Главные тектони- } \\
\text { ческие нарушения, } \\
\text { вдоль которых груп- } \\
\text { пируется серебряное } \\
\text { оруденение }\end{array}$ & $\begin{array}{l}\text { Конгинский субмери- } \\
\text { диональный глубин- } \\
\text { ный разлом, по кото- } \\
\text { рому сформировалась } \\
\text { протяженная (250 км) } \\
\text { ветвь вулканитов } \\
\text { ОЧВП меридиональ- } \\
\text { ного простирания } \\
\end{array}$ & $\begin{array}{l}\text { Джолсай-Учимский } \\
\text { сброс длиной } 60 \text { км } \\
\text { и Курганский сброс } \\
\text { длиной } 25 \text { км }\end{array}$ & $\begin{array}{l}\text { Две региональные } \\
\text { зоны, пересекаю- } \\
\text { щиеся у Яхимова }\end{array}$ & $\begin{array}{l}\text { Региональный } \\
\text { сброс Осборн } \\
\text { протяженностью } \\
\text { более } 50 \text { км }\end{array}$ \\
\hline $\begin{array}{l}\text { Структурный кон- } \\
\text { троль }\end{array}$ & $\begin{array}{l}\text { Выступы кристалли- } \\
\text { ческого фундамента. } \\
\text { Послойные трещины } \\
\text { сжатия и растяжения } \\
\text { в известковистых тол- } \\
\text { щах и вертикальные } \\
\text { трещины скола }\end{array}$ & $\begin{array}{l}\text { В сбросовых опе- } \\
\text { ряющих наруше- } \\
\text { ниях и трещинах, в } \\
\text { пологих трещинах } \\
\text { отрыва }\end{array}$ & $\begin{array}{l}\text { Восточная часть } \\
\text { Саксоно-Тюрингин- } \\
\text { ской зоны мозаичного } \\
\text { сложения (палеозой- } \\
\text { ское эпиплатфор- } \\
\text { менное обрамление } \\
\text { древнего Чешского } \\
\text { массива) }\end{array}$ & $\begin{array}{l}\text { В лежачем боку } \\
\text { сброса Осборн и } \\
\text { в оперяющих тре- } \\
\text { щинах }\end{array}$ \\
\hline Жильные минералы & $\begin{array}{l}\text { Кальцит, мангано- } \\
\text { кальцит, манганоси- } \\
\text { дерит, реже кварц, } \\
\text { флюорит }\end{array}$ & $\begin{array}{l}\text { Манганосидерит, } \\
\text { анкерит, частично } \\
\text { кальцит }\end{array}$ & $\begin{array}{l}\text { Сидерит, анкерит, } \\
\text { манганосидерит, ро- } \\
\text { дохрозит, реже кварц } \\
\text { и барит } \\
\end{array}$ & $\begin{array}{l}\text { Сидерит, кварц, } \\
\text { анкерит, прочие } \\
\text { карбонаты, реже } \\
\text { барит }\end{array}$ \\
\hline $\begin{array}{l}\text { Основные серебро- } \\
\text { содержащие мине- } \\
\text { ралы }\end{array}$ & $\begin{array}{l}\text { Акантит, аргенто- } \\
\text { пирит, штернбергит, } \\
\text { стефанит, прустит, } \\
\text { галенит, фрейбергит, } \\
\text { биллингслеит }\end{array}$ & $\begin{array}{l}\text { Блеклые руды, акан- } \\
\text { тит, прустит, пирар- } \\
\text { гирит, галенит }\end{array}$ & \begin{tabular}{|} 
Блеклые руды, фрей- \\
бергит, сурьмяно- \\
мышьяковые сульфо- \\
соли серебра
\end{tabular} & $\begin{array}{l}\text { Тетраэдрит, гале- } \\
\text { нит }\end{array}$ \\
\hline $\begin{array}{l}\text { Минералого-геохи- } \\
\text { мические особен- } \\
\text { ности }\end{array}$ & $\begin{array}{l}\text { Наложенные на га- } \\
\text { ленит арсенопирит } \\
\text { и леллингит, а также } \\
\text { присутствие нике- } \\
\text { листого кобальтина, } \\
\text { мышьяковистого } \\
\text { акантита }\end{array}$ & $\begin{array}{l}\text { Наличие самородно- } \\
\text { го серебра и висму- } \\
\text { та, редкие находки } \\
\text { сульфидов и суль- } \\
\text { фоарсенидов ни- } \\
\text { келя, повышенные } \\
\text { содержания сурьмы } \\
\text { и висмута } \\
\end{array}$ & $\begin{array}{l}\text { Наличие самород- } \\
\text { ного серебра, вис- } \\
\text { мута, урана, а также } \\
\text { минералов никеля и } \\
\text { кобальта }\end{array}$ & $\begin{array}{l}\text { Низкое содержа- } \\
\text { ние свинца в сереб- } \\
\text { ряных рудах; на- } \\
\text { личие на глубоких } \\
\text { горизонтах урана, } \\
\text { редкие находки ко- } \\
\text { бальтовых и нике- } \\
\text { левых минералов } \\
\end{array}$ \\
\hline $\begin{array}{l}\text { Месторождения, py- } \\
\text { допроявления }\end{array}$ & $\begin{array}{l}\text { Седое, Ущельное, } \\
\text { Правое Визульное, } \\
\text { Ольдяни, Риф }\end{array}$ & $\begin{array}{l}\text { Кумыштаг, Джолсай, } \\
\text { Кен-Шанык }\end{array}$ & $\begin{array}{l}\text { Шнееберг, Яхимов, } \\
\text { Гроба, Циновца }\end{array}$ & $\begin{array}{l}\text { Саншайн, Поля- } \\
\text { рис, Силвер-Сам- } \\
\text { мит, Рок-Крик }\end{array}$ \\
\hline
\end{tabular}

\footnotetext{
* Коледа, 1974.
}

** Антонов, 2009. 


\section{ЗАКЛЮЧЕНИЕ}

Таким образом, можно констатировать, что полученные нами результаты изучения самородков серебра из шлиховых ореолов, позволяют считать, что мы имеем дело с серебро-арсенидной формацией на Омолонском срединном массиве. Примерами подобного оруденения служат «благородные формации» Рудных Гор, а также аналогичные проявления, подробно изученные и описанные для Киргизии, как серебро-карбонатный комплекс рудных формаций в Таласском хребте Тянь-Шаня (Антонов, Четырбоцкая, 1979; Коваленкер и др., 1994).

Поскольку в Южно-Омолонском рудном районе в породах основания развиты месторождения железистых кварцитов с высокими концентрациями $\mathrm{Fe}$, то можно прогнозировать обнаружение проявлений не только серебро-арсенидной, но и, возможно, пятиэлементной формации в зонах тектономагматической активизации вдоль Конгинского глубинного разлома и сближенных с ним выходов древнего фундамента.

Автор выражает благодарность Е. М. Горячевой за выполнение большого объема микрорентгеноспектральных анализов.

\section{ЛИТЕРАТУРА}

Антонов А. Е. Зарубежные месторождения серебpa : 2-е изд., доп. М. : ГЕОС, 2009. 312 c.

Антонов А. Е., Четырбоикая И. И. Основные черты металлогении серебра Тянь-Шаня // Металлогения орогенных этапов развития Тянь-Шаня / IX Bceсоюз. металлогенич. совещ. : тез. докл. Ташкент, 1979. C. $156-157$.

Геология и металлогения фанерозойских комплексов юга Омолонского массива / отв. ред. Н. А. Горячев. Владивосток : Дальнаука, 2017. 312 с.

Коваленкер В. А., Левин К. А., Наумов В. Б. и др. Условия формирования богатых серебро-арсенид- ных руд месторождения Актепе (Срединный ТяньШань) // Геохимия. 1994. № 5. С. 718-731.

Коледа А. Я. О серебряном оруденении Таласского хребта // Разведка и охрана недр. 1974. № 4. C. $18-20$.

Павлов Г. Ф., Савва Н. Е., Хорин Г. И. и др. Самородное серебро в россыпях Северо-Востока СССР // Минералы и минеральные парагенезисы пород и руд Северо-Востока СССР. Магадан : СВКНИИ ДВНЦ AH CCCP, 1986. C. 77-89.

Показаньев В. П., Вялов А. Г., Пчелинцева Р. Б. Вопросы металлогении Абкитского плутона // Материалы по геол. и полез. ископ. Северо-Востока СССР. Магадан, 1980. Вып. 25. С. 130-137.

Савва Н. Е. Минералогия серебра Северо-Востока России / [науч. ред. А. А. Сидоров]; Сев.-Вост. комплекс. НИИ ДВО РАН. М. : Триумф, 2018. 544 с. (Тр. СВКНИИ ДВО РАН ; вып. 78). DOI: 10.32986/978-589392-823-5-1-544.

Савва Н. Е., Ведерников В. Н. Новый тип серебряной минерализации на Северо-Востоке СССР // Геохимия и минералогия рудных месторождений Северо-Востока СССР. Магадан : СВКНИИ ДВО PAH, 1989. C. 86-97.

Савва H. E. Серебро-арсенидная россыпеобразующая формация Омолонского срединного массива // Геология и минерагения Северо-Востока Азии : тез. докл. Х сессии СВО МО РАН. Магадан : СВКНИИ ДВО РАН, 1999. С. 47-49.

Сидоров А. А., Старостин В. И., Волков А. В. Рудноформационный анализ. М. : МАКС Пресс, 2011. 180 с.

Смирнов В. И. Геология полезных ископаемых М. : Недра, 1982. 669 с.

Шпикерман В. И., Чернышев И. В., Агапова А. А., Троицкий $B$. А. Геология изотопов рудного свинца центральных районов Северо-Востока России. Магадан : СВКНИИ ДВО РАН, 1993. $36 \mathrm{c}$.

Changkakoti A., Morton R. D. Electron microprobe analyses of native silver and associated arsenides from the Great Bear Lake silver deposits, Northwest Territories, Canada // Canadian Journal of Earth Sciences. 1986 Vol. 23, No. 10. P. 1470-1479.

Поступила в редакциию 28.06.2019 2.

Поступила после доработки 10.07.2019 г.

\title{
SILVER-ARSENIDE TYPE OF THE OMOLON MASSIF (New Data)
}

\begin{abstract}
N. E. Savva
North-East Interdisciplinary Scientific Research Institute n. a. N. A. Shilo, FEB RAS, Magadan

Silver nuggets from concentrate aureoles of the Sedoy occurrence have been studied. In the intergrowth with native silver, custelite, uytenbogaardtite, billingsleyite $\mathrm{Ag}_{7}(\mathrm{Sb}, \mathrm{As}) \mathrm{S}_{6}$, xanthoconite $\mathrm{Ag}_{3} \mathrm{AsS}_{3}$, acanthite and arsenious acanthite (As to $2.8 \mathrm{wt} . \%$ ), sphalerite, electrum, nickelous cobaltite (Ni to 4 wt.\%), nickelous threchmannite $\mathrm{AgAsS}_{2}$, which deflates an earlier assumption on the exogenous origin of nuggets and confirms the silver-arsenide ore formation of Sedoy. It is shown that the concentrate aureoles of native silver located along the Konghinsky deep-seaated fault indicate the manifestation of the silver-arsenide formation in the area of the Omolon median massif.
\end{abstract}

Keywords: native silver, silver-arsenide formation, Omolon median massif. 


\section{REFERENCES}

Antonov, A. E., 2009, Foreign Deposits of Silver, $2^{\text {nd }}$ Ed., Revised, Moscow, GEOS [In Russian].

Antonov, A. E.; Chetyrbotskaya, I. I., 1979, Main Features of the Tien Shan Silver Metallogeny, Metallogeny of Orogenic Stages in the Tien Shan Development, IX AllUnion Metallogenic Meeting, Abstracts, Tashkent, 156157 [In Russian].

Changkakoti, A.; Morton, R. D., 1986, Electron Microprobe Analyses of Native Silver and Associated Arsenides from the Great Bear Lake Silver Deposits, Northwest Territories, Canada, Canadian Journal of Earth Sciences, 23, 10, 1470-1479.

Geology and Metallogeny of Phanerozoic Complexes in the South of the Omolon Massif, 2017, Ed. N. A. Goryachev, Vladivostok, Dalnauka [In Russian].

Koleda, A. Y., 1974, On Silver Mineralization in the Talas Ridge, Prospecting and Protection of Subsurface, 4, 18-20 [In Russian].

Kovalenker, V. A.; Levin, K. A.; Naumov, V. B., et al., 1994, Formation Conditions of Rich Silver-Arsenide Ores of the Aktepe Deposit (Central Tien Shan), Geochemistry International , 5, 718-731 [In Russian].

Pavlov, G. F.; Savva, N. E.; Khorin, G. I.; Teplykh, V. I.; Tovma, I. T.; Zharikhin, K. G.; Bulyakov, G. Kh., 1986, Native Silver in Placers of the North-East of the USSR, Minerals and Mineral Parageneses of Rocks and Ores of the North-East of the USSR, Magadan, SVKNII DVNC AN USSR, 77-89 [In Russian].
Pokazanyev, V. P.; Vyalov, A. G.; Pchelintseva, R. B., 1980, Issues of the Abkit Pluton Metallogeny, Materials on Geology and Mineral Resources of the North-East of the USSR, Magadan, 25, 130-137 [In Russian].

Savva, N. E., 1999, Silver-Arsenide Placer Formation of the Omolon Median Massif, Geology and Metallogeny of Northeast Asia, Abstracts, X Session of the North-East Division of the RAS Mineralogical Society , Magadan, NEISRI FEB RAS, 47-49 [In Russian].

Savva, N. E., 2018, Mineralogy of Silver in the NorthEast of Russia, Works of NEISRI FEB RAS, Ed. A. A. Sidorov, 78, Moscow, Triumph, DOI: 10.32986/978-589392-823-5-1-544 [In Russian].

Savva, N. E.; Vedernikov, V. N., 1989, New Type of Silver Mineralization in the North-East of the USSR, Geochemistry and Mineralogy of Ore Deposits in the North-East of the USSR, Magadan, SVKNII DVNC AN USSR, DOI: 10.32986/978-5-89392-823-5-1-544 [In Russian].

Shpikerman, V. I.; Chernyshev, I. V.; Agapova, A. A.; Troitsky, V. A., 1993, Geology of Ore Lead Isotopes in Central Areas of Northeast Russia, Magadan, NEISRI FEB RAS [In Russian].

Sidorov, A. A.; Starostin, V. I.; Volkov, A. V., 2011, OreInformation Analysis, Moscow, MAKS Press [In Russian]. Smirnov, V. I., 1982, Geology of Mineral Resources, Moscow, Nedra [In Russian]. 